\title{
44. DATA REPORT: INDIAN OCEAN OLIGOCENE STRONTIUM ISOTOPE STRATIGRAPHY, LEGS 119-121, KERGUELEN PLATEAU AND NINETYEAST RIDGE ${ }^{1}$
}

\author{
James J. Pospichal, ${ }^{2}$ Wuchang Wei, ${ }^{2}$ Sherwood W. Wise, Jr. $^{2}$
}

\begin{abstract}
Strontium isotope $\left({ }^{87} \mathrm{Sr} /{ }^{86} \mathrm{Sr}\right)$ ages have been established for Oligocene samples of Leg 119 Site 744 , Leg 120 Sites 747 and 748 , and Leg 121 Sites 756 and 757. Ages were determined using the strontium isotope age equation of Miller et al. (1988) and preliminary correlations have been made with available nannofossil biostratigraphy. The strontium isotope ages calculated here augment biostratigraphy, which for the Oligocene is characterized by long biozones, and provide additional detail where the paleomagnetic record is not clear (Sites 756 and 757). Results from the lower latitude Ninetyeast Ridge sites where standard calcareous nannofossil datums are present are compared to those of the higher latitude Kerguelen Plateau sites in order to examine biostratigraphic events across latitude in the Indian Ocean. The ${ }^{87} \mathrm{Sr} /{ }^{86} \mathrm{Sr}$ determined ages are used here as a tool for correlation.
\end{abstract}

\section{INTRODUCTION}

Recently, the application of ${ }^{87} \mathrm{Sr} /{ }^{86} \mathrm{Sr}$ ratios to age determination has proven to be a useful tool for greater stratigraphic precision of Oligocene and Miocene deep-sea sediments (Burke et al., 1982; DePaolo and Ingram, 1985; Miller et al., 1988; Hess et al., 1989; Barrera et al., in press). The ${ }^{87} \mathrm{Sr} /{ }^{86} \mathrm{Sr}$ ratio is considered to be uniform throughout the world's oceans at a given time (Broecker and Peng, 1982). Thus, rapid variations such as those preserved in Oligocene and Miocene carbonates are considered synchronous across latitudes, thereby providing a precise method for correlating deep sea sections from different latitudes and ocean basins. As with magnetostratigraphy, strontium isotope stratigraphy can provide more precision where biostratigraphic zones are long or where fossil datums are diachronous across latitude and/or longitude.

We have presented here a preliminary report of our measurements of the ${ }^{87} \mathrm{Sr} /{ }^{86} \mathrm{Sr}$ values from biostratigraphically dated Oligocene samples from Leg 119 Site 744, Leg 120 Sites 747 and 748 , and Leg 121 Sites 756 and 757 (Fig 1). Magnetostratigraphy was not established for Sites 756 and 757 but is available from Site 744 . Sites 744,747 , and 748 are located on the Kerguelen Plateau in the southern Indian Ocean and Sites 756 and 757 on the Ninetyeast Ridge in the east-central Indian Ocean. These sites provide a transect through the Indian Ocean which encompasses a wide latitudinal range. The Ninetyeast Ridge Sites 756 and 757 have an estimated paleolatitude of $40^{\circ}-45^{\circ} \mathrm{S}$ and $30^{\circ}-35^{\circ} \mathrm{S}$, respectively, for the Oligocene (Peirce, 1978; Royer and Sandwell, 1989 ) and provide the middle-latitude section. Site 744 at $61^{\circ} \mathrm{S}$ provides the extreme high-latitude section while Sites $747\left(54^{\circ} \mathrm{S}\right)$ and $748\left(58^{\circ} \mathrm{S}\right)$ provide the intermediate sections. The data described here will be the subject of more rigorous interpretations presented in a subsequent publication. In addition, a preliminary set of strontium data from selected samples from South Atlantic DSDP Sites 329 and 513 and ODP Sites 689 and 690 are presented in the Appendix.

\footnotetext{
'Weissel, J., Peirce, J., Taylor, E., Alt, J., et al., 1991. Proc. ODP, Sci. Results, 121: College Station, TX (Ocean Drilling Program).

${ }^{2}$ Department of Geology, Florida State University, Tallahassee, FL 32306, U.S.A.
}

\section{METHODS}

Strontium isotopes were analyzed on approximately 300 specimens of mixed planktonic foraminifer species picked from the greater than $150 \mu \mathrm{m}$ size fraction and dissolved in 3N HCL. Standard ion exchange techniques (e.g., Hart and Brooks, 1974) were used to separate strontium for analysis on a VG Sector mass spectrometer at Rutgers University. Internal precision (intra-run variability) on the Sector is approximately \pm 0.000008 (mean $2 \sigma$ error for 69 analyses at Site 608, Millet et al., 1991; external precision (inter-run variability) is on the order of \pm 0.000030 or better (Miller et al., 1991). At Rutgers, NBS 987 is routinely measured as 0.710252 ( $2 \sigma$ standard deviation $0.000026 ; n=35$ ) normalized to ${ }^{86} \mathrm{Sr} /{ }^{88} \mathrm{Sr}$ of 0.1194 (Miller et al., 1991).

Absolute ages were calculated using the following equation of Miller et al. (1988) which was established from data of South Atlantic DSDP (Deep Sea Drilling Project) Site 522:

$$
\text { Age }(\mathrm{Ma})=20392.79-28758.84\left({ }^{87} \mathrm{Sr} /{ }^{86} \mathrm{Sr}\right)
$$

\section{FORAMINIFER PRESERVATION}

The effects of diagenesis on ${ }^{87} \mathrm{Sr} /{ }^{86} \mathrm{Sr}$ ratios in foraminifer tests is not completely understood. Dissolution and reprecipitation of calcite can alter the $\mathrm{Sr}$ isotope composition of foraminifer tests if pore water ${ }^{87} \mathrm{Sr} /{ }^{86} \mathrm{Sr}$ ratios are significantly different from that of the tests themselves. Several sources that normally can have ${ }^{87} \mathrm{Sr} /{ }^{86} \mathrm{Sr}$ ratios different than the carbonate deposits and which can potentially supply $\mathrm{Sr}$ to interstitial waters include basalts, volcanic ash, or older and younger carbonate sediments (Elderfield and Gieskes, 1982; Elderfield et al., 1982; Gieskes et al., 1986; Hess et al., 1989; Barrera et al., in press).

The planktonic foraminifer specimens picked for this study are for the most part moderately preserved. According to van Eijden and Smit (this volume), preservation of planktonic foraminifers from the Oligocene of Leg 121 Site 756 is good, but at Site 757, specimens show signs of dissolution. Preservation of Oligocene specimens from Leg 119 Site 744 is good (Barron, Larsen, et al., 1989). Specimens from Leg 120 Sites 747 and 748 are also well preserved.

\section{RESULTS}

\section{Site 744}

The strontium data for Site 744 are shown in Table 1 and graphically displayed in Figure 2. The strontium ages as calcu- 


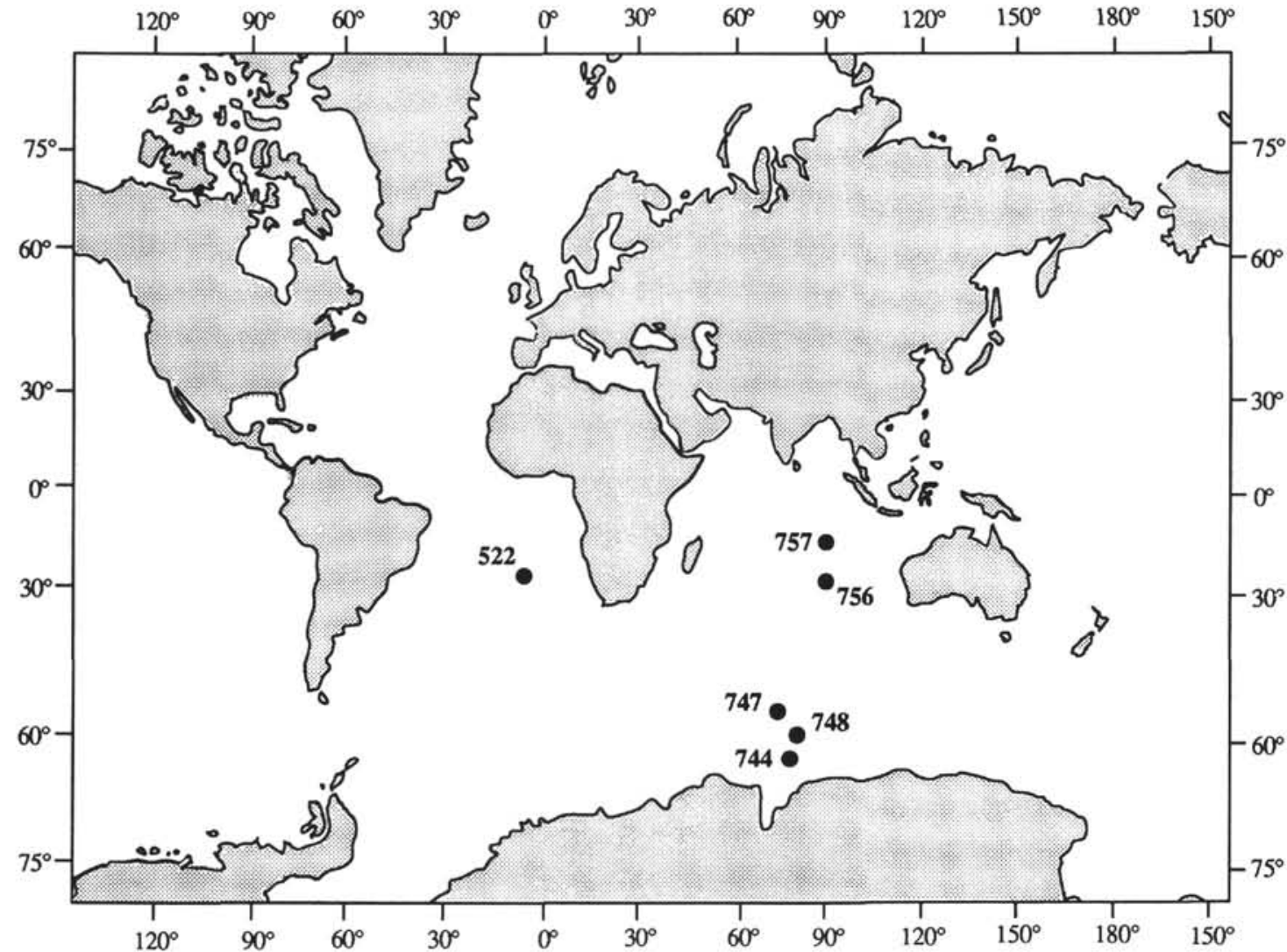

Figure 1. Location map of DSDP Site 522 (South Atlantic) and ODP Kerguelen Plateau Sites 744, 747, and 748, and Ninetyeast Ridge Sites 756 and 757.

Table 1. Age and depths of ${ }^{87} \mathrm{Sr} /{ }^{86} \mathrm{Sr}$ ratios, magnetostratigraphic, and biostratigraphic events of samples from Kerguelen Plateau Site 744. The biostratigraphy includes calcareous nannofossil, planktonic foraminifer, diatom, and radiolarian data.

\begin{tabular}{|c|c|c|c|c|c|c|c|c|}
\hline $\begin{array}{l}\text { Depth } \\
\text { (mbsf) }\end{array}$ & $\begin{array}{l}\text { Strontium } \\
\text { age (Ma) }\end{array}$ & Sample & Strontium & Error & $\begin{array}{l}\text { Depth } \\
\text { (mbsf) }\end{array}$ & $\begin{array}{l}\text { Paleomagnetic } \\
\text { age (Ma) }\end{array}$ & $\begin{array}{l}\text { Depth } \\
\text { (mbsf) }\end{array}$ & $\begin{array}{c}\text { Biostratigraphic } \\
\text { age (Ma) }\end{array}$ \\
\hline 99.20 & 24.053 & $11, \mathrm{CC}$ & 0.708260 & 0.000008 & 93.00 & 20.45 & 90.60 & 19.90 \\
\hline 108.70 & 27.359 & $12, \mathrm{CC}$ & 0.708145 & 0.000006 & 94.60 & 20.88 & 95.00 & 22.20 \\
\hline 118.20 & 31.129 & $13, \mathrm{CC}$ & 0.708014 & 0.000013 & 96.60 & 21.16 & 97.00 & 21.70 \\
\hline 127.70 & 33.314 & $14, \mathrm{CC}$ & 0.707938 & 0.000008 & 97.76 & 24.04 & 99.00 & 24.00 \\
\hline 136.00 & 34.463 & $15-6,75-76 \mathrm{~cm}$ & 0.707898 & 0.000005 & 99.00 & 26.38 & 99.60 & 23.60 \\
\hline 145.00 & 37.973 & $18-2$ & 0.707776 & 0.000005 & 100.10 & 26.56 & 107.00 & 25.50 \\
\hline \multirow[t]{16}{*}{166.60} & 39.324 & $19, \mathrm{CC}$ & 0.707729 & 0.000006 & 104.80 & 26.86 & 109.00 & 28.20 \\
\hline & & & & & 111.80 & 27.74 & 110.00 & 26.20 \\
\hline & & & & & 115.30 & 28.15 & 117.80 & 30.10 \\
\hline & & & & & 118.35 & 32.06 & 118.60 & 32.00 \\
\hline & & & & & 119.20 & 32.00 & 122.00 & 32.00 \\
\hline & & & & & 125.00 & 32.90 & 124.00 & 33.00 \\
\hline & & & & & 139.25 & 35.29 & 127.00 & 32.20 \\
\hline & & & & & 146.60 & 35.87 & 128.00 & 33.00 \\
\hline & & & & & 155.60 & 37.24 & 130.00 & 34.80 \\
\hline & & & & & 158.00 & 37.68 & 147.00 & 35.50 \\
\hline & & & & & 161.60 & 38.10 & 148.00 & 36.00 \\
\hline & & & & & 162.80 & 38.34 & 157.60 & 37.10 \\
\hline & & & & & 164.80 & 38.50 & 167.00 & 38.00 \\
\hline & & & & & 167.20 & 38.79 & 170.00 & 38.80 \\
\hline & & & & & 170.20 & 38.83 & & \\
\hline & & & & & 172.80 & 39.24 & & \\
\hline
\end{tabular}



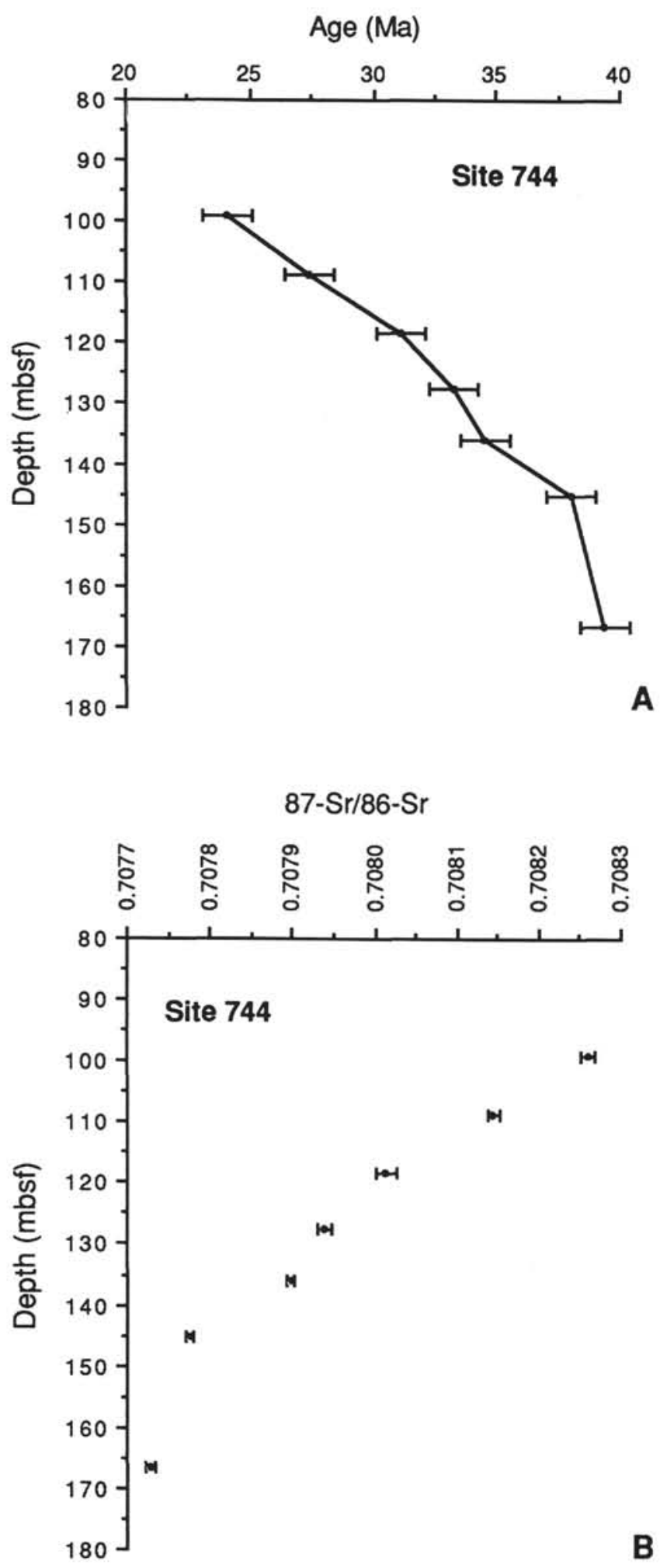

Figure 2. A. Strontium isotope age/depth plot for Kerguelen Plateau Site 744 Oligocene samples. B. Site $744{ }^{87} \mathrm{Sr} / 86 \mathrm{Sr}$ values vs. depth. (Data listed in Table 1.) lated indicate an age of $39.32 \mathrm{Ma}$ for the lowermost sample analyzed (119-744A-19H-CC, $166.6 \mathrm{mbsf})$ and 24.05 for the uppermost sample (119-744A-11H-CC, $99.20 \mathrm{mbsf})$. The ${ }^{87} \mathrm{Sr} /{ }^{86} \mathrm{Sr}$ values uniformly decrease upsection (Fig. 2B), which indicates a rather uniform sedimentation rate as well, shown in Figure 2A. These values agree somewhat with Barrera et al. (in press) who have measured ${ }^{87} \mathrm{Sr} /{ }^{86} \mathrm{Sr}$ in the same section at Site 744. Their data indicate a possible hiatus between Cores 119$744 \mathrm{~A}-11 \mathrm{H}$ and $-12 \mathrm{H}$. However, since we have only measured one sample per core whereas Barrera et al. (in press) have measured several, this hiatus is not detected by our analysis.

Except for one data point at approximately $146.0 \mathrm{mbsf}$, all our data points agree remarkably well with those of the magnetostratigraphy, which is constrained by the biostratigraphic data (Fig. $3)$. It is also notable that the two strontium isotope dates that Barrera et al. (in press) obtained at $148.57 \mathrm{mbsf}$ and $150.0 \mathrm{mbsf}$ are also significantly younger than the biomagnetostratigraphic dates for this interval.

\section{Site 747}

For Site 747, those data are presented in Table 2 and graphically depicted in Figure 4 . The ${ }^{87} \mathrm{Sr} /{ }^{86} \mathrm{Sr}$ values measured at this site present some problems in age determination (Fig. 4A). The values do not continually increase upsection as expected but fluctuate (Fig. 4B). For example, the values for the lowest sample analyzed (120-747A-17X-5, 10-12 cm, $157.6 \mathrm{mbsf})$ indicate an age of $28.48 \mathrm{Ma}$, but $15 \mathrm{~m}$ upsection an age of $28.66 \mathrm{Ma}$ is calculated for Sample 120-747 A-16H-1, 10-12 cm (142.10 mbsf). The uppermost sample (120-747A-11 H-4, 10-11 cm, $99.10 \mathrm{mbsf})$ has a calculated age of $22.01 \mathrm{Ma}$, which is not the youngest age as indicated by the ${ }^{87} \mathrm{Sr} /{ }^{86} \mathrm{Sr}$ values (Fig. 4A). An age of 15.33 $\mathrm{Ma}$ is calculated for Sample 120-747A-13H-4, 10-11 cm. The reasons for these anomalous values is uncertain and may be attributed to a number of problems. Diagenetic effects cannot be ruled out, however they are unlikely since foraminifer preservation is very good. Core recovery was very good and with little

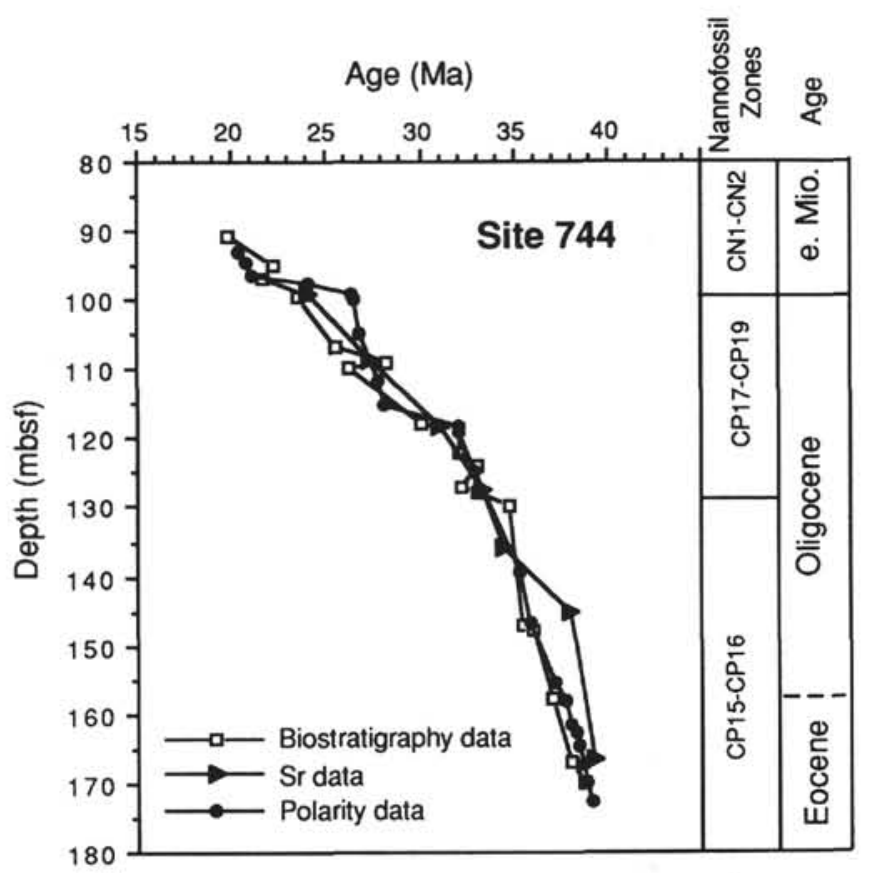

Figure 3. Age/depth plot constructed from strontium isotope values, magnetostratigraphy, and biostratigraphy for the Oligocene of Kerguelen Plateau Site 744. (Data listed in Table 1.) 
Table 2. Age and depth of ${ }^{87} \mathrm{Sr} /{ }^{86} \mathrm{Sr}$ values of samples from Kerguelen Plateau Site 747.

\begin{tabular}{rcccc}
\hline $\begin{array}{c}\text { Depth } \\
\text { (mbsf) }\end{array}$ & $\begin{array}{c}\text { Strontium } \\
\text { age (Ma) }\end{array}$ & Sample & Strontium & Error \\
\hline 99.10 & 22.012 & $11-4,10-11 \mathrm{~cm}$ & 0.708331 & 0.000008 \\
108.60 & 18.646 & $12-4,10-11 \mathrm{~cm}$ & 0.708448 & 0.000013 \\
118.10 & 15.223 & $13-4,10-11 \mathrm{~cm}$ & 0.708567 & 0.000009 \\
124.60 & 24.254 & $14-2,10-12 \mathrm{~cm}$ & 0.708253 & 0.000006 \\
129.10 & 25.924 & $14-6,10-12 \mathrm{~cm}$ & 0.708195 & 0.000006 \\
134.10 & 27.104 & $15-2,10-12 \mathrm{~cm}$ & 0.708154 & 0.000006 \\
138.60 & 25.980 & $15-5,10-12 \mathrm{~cm}$ & 0.708193 & 0.000006 \\
142.10 & 28.656 & $16-1,10-12 \mathrm{~cm}$ & 0.708100 & 0.000005 \\
145.10 & 27.850 & $16-3,10-12 \mathrm{~cm}$ & 0.708128 & 0.000014 \\
148.10 & 28.166 & $16-5,10-12 \mathrm{~cm}$ & 0.708117 & 0.000006 \\
153.10 & 28.109 & $17-2,10-12 \mathrm{~cm}$ & 0.708119 & 0.000045 \\
157.60 & 28.482 & $17-5,10-12 \mathrm{~cm}$ & 0.708106 & 0.000004 \\
\hline
\end{tabular}

drilling disturbance (Schlich, Wise, et al., 1989). Error in preparation and/or measurement of ${ }^{87} \mathrm{Sr} /{ }^{86} \mathrm{Sr}$ values is likely to have occurred. Considering the difficulties presented by the strontium analysis, the results will not be discussed in further comparison to the biostratigraphy.

\section{Site 748}

The strontium analysis of samples from Site 748 is given in Table 3 and plotted in Figure 5. The age of the samples analyzed from this site range from $25.28 \mathrm{Ma}$ in the uppermost sample (120-748B-8H-1, 58-62 cm, 57.68 mbsf) to $39.67 \mathrm{Ma}$ in Sample 120-748B-15H-5, 10-11 cm (129.7 mbsf) (Fig. 5A). The ${ }^{87} \mathrm{Sr} /{ }^{86} \mathrm{Sr}$ values increase with decreasing depth through the section analyzed with minor fluctuations in the samples from 87.0 to 100.0 mbsf (Fig. 5B). The erratic values through this interval may also be attributed to the aforementioned error possibilities.

At Site 748 , the strontium ages are in good agreement with the nannofossil data at least through the lower Oligocene (Fig. 6). A slight disparity in the middle to upper Oligocene may be due to the fact that fewer nannofossil datums with correlated absolute dates are available in this interval. The samples assigned absolute ages which are correlated to nannofossil datums are given in Wei et al. (in press), who were only able to use a few conventional datums because of the absence of marker species at this high-latitude location (Table 3). The strontium-determined Eocene/Oligocene boundary correlates well with the estimate from nannofossils for this horizon. This is encouraging since the standard nannofossil marker event used to indicate this boundary is the last occurrence (LO) of Discoaster saipanensis and D. barbadiensis, species which are rare to absent at these high latitudes. This indicates that the alternative marker species, Reticulofenestra oamaruensis, employed by Wei et al. (in press), may be an adequate proxy for the high-latitude Eocene/Oligocene boundary (36.7 Ma, Berggren et al., 1985). The LO of this species is noted slightly above the boundary with an estimated age of $36.0 \mathrm{Ma}$.

\section{Site 756}

Strontium data for Ninetyeast Ridge Site 756 are given in Table 4 and shown in Figure 7. The lowermost sample (121-756C$7 \mathrm{X}-5,45-46 \mathrm{~cm}, 136.25 \mathrm{mbsf}$ ) is assigned an age of $37.54 \mathrm{Ma}$ and the uppermost sample (121-756B-8H-2, 45-46 cm, $67.55 \mathrm{mbsf}$ ), an age of $24.6 \mathrm{Ma}$ (Fig. 7A). The ${ }^{87} \mathrm{Sr} /{ }^{86} \mathrm{Sr}$ values shown in Figure 7B generally increase with decreasing depth as expected, however, anomalous fluctuations in the data are present between about 95.0 and $110.0 \mathrm{mbsf}$. On the age/depth plot of Figure $7 \mathrm{~A}$, the fluctuations are seen as an abrupt offset at about $100.0 \mathrm{mbsf}$, which is coincident with the break between the bottom sample of Hole 756B (Sample 121-756B-11H-5, 45-46 cm, $101.05 \mathrm{mbsf}$ )
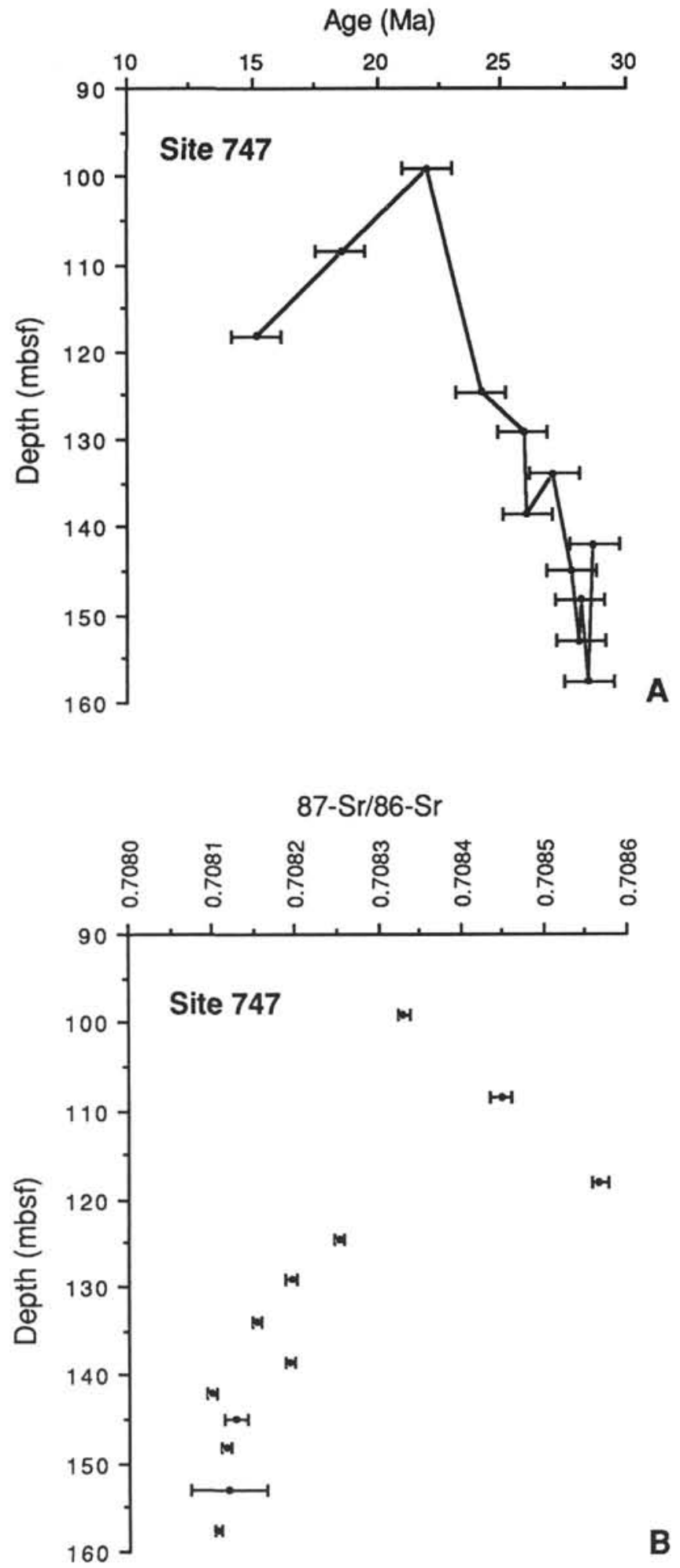

Figure 4. A. Strontium isotope age/depth plot for Kerguelen Plateau Site 747 Oligocene samples. B. Site $747^{87} \mathrm{Sr} /{ }^{86} \mathrm{Sr}$ values vs. depth. (Data listed in Table 2.) 
Table 3. Age and depths of ${ }^{87} \mathrm{Sr} /{ }^{86} \mathrm{Sr}$ ratios and calcareous nannofossil biostratigraphic events of samples from Kerguelen Plateau Site 748.

\begin{tabular}{rcccccc}
\hline $\begin{array}{c}\text { Depth } \\
\text { (mbsf) }\end{array}$ & $\begin{array}{c}\text { Strontium } \\
\text { age (Ma) }\end{array}$ & Sample & Strontium & Error & $\begin{array}{r}\text { Depth } \\
\text { (mbsf) }\end{array}$ & $\begin{array}{c}\text { Biostragraphic } \\
\text { age (Ma) }\end{array}$ \\
\hline 57.68 & 25.28 & $8-1,58-62 \mathrm{~cm}$ & 0.708217 & 0.000072 & 66.68 & 24.00 \\
68.20 & 27.10 & $9-2,10-11 \mathrm{~cm}$ & 0.708154 & 0.000025 & 73.45 & 27.00 \\
72.70 & 27.77 & $9-5,10-11 \mathrm{~cm}$ & 0.707960 & 0.000009 & 104.45 & 33.00 \\
87.20 & 32.57 & $11-2,10-11 \mathrm{~cm}$ & 0.707964 & 0.000020 & 109.95 & 34.60 \\
91.70 & 31.90 & $11-5,10-11 \mathrm{~cm}$ & 0.707987 & 0.000008 & 115.90 & 36.00 \\
96.70 & 32.68 & $12-2,10-11 \mathrm{~cm}$ & 0.708131 & 0.000009 & 125.95 & 38.50 \\
101.20 & 32.19 & $12-5,10-11 \mathrm{~cm}$ & 0.707977 & 0.000030 & 127.45 & 39.00 \\
106.20 & 34.55 & $13-2,10-11 \mathrm{~cm}$ & 0.707895 & 0.000006 & & \\
106.20 & 34.38 & $13-2,10-11 \mathrm{~cm}$ & 0.707901 & 0.000014 & & \\
116.60 & 37.46 & $14-2,100-104 \mathrm{~cm}$ & 0.707794 & 0.000004 & & \\
125.20 & 37.74 & $15-2,10-11 \mathrm{~cm}$ & 0.707784 & 0.000004 & & \\
129.70 & 39.67 & $15-5,10-11 \mathrm{~cm}$ & 0.707717 & 0.000005 & & \\
\hline
\end{tabular}

and the topmost sample of Hole 756C (Sample 121-756C-4X-2, $45-46 \mathrm{~cm}, 102.85 \mathrm{mbsf}$ ). Other than analytical error, it is possible that the anomalous shift toward older ages going upsection between Holes 756B and 756C is the result of a shipboard miscalculation of sub-bottom depths. There was some concern aboard ship that this may have occurred for Hole $756 \mathrm{C}$, but the problem was not resolved. Two initial cores were taken in this hole and the third was washed an estimated $22.3 \mathrm{~m}$ before Core $121-756 \mathrm{C}-4 \mathrm{X}$ was taken at a depth calculated to coincide with the bottom of nearby Hole 756B. Errors may have occurred during this process. On the other hand, it is unlikely, but not impossible, that a fault is present between the two holes, which are offset by only $200 \mathrm{~m}$. There is no paleontological evidence for either this, slumping, or intense reworking. If the sub-bottom depths for cores of Hole $756 \mathrm{C}$ are adjusted a minimum of $15 \mathrm{~m}$ upward, that is if the bottom of Hole $756 \mathrm{~B}$ really overlaps by $15 \mathrm{~m}$ with Hole $756 \mathrm{C}$, then the anomalous shift is all but eliminated. This does not conflict with the biostratigraphy since the adjusted interval occurs all within a single biozone, CP18. Such an adjustment would condense this zone slightly, which would actually make its sedimentation rate more consistent with overall rates through the entire Oligocene.

The strontium values generally agree very well with the calcareous nannofossil data of Resiwati (P. Resiwati, pers. comm.) (Fig. 8). As at previously discussed sites, the greatest disparity between strontium and nannofossil ages occurs in an interval of low biostratigraphic resolution corresponding to the middle Oligocene. Also notable at this site, as at Site 748 , is the close agreement between the two methods as to the placement of the Eocene/Oligocene boundary. The boundary at this middle latitude site is biostratigraphically determined by the LO of Discoaster saipanensis and D. barbadiensis, where, as mentioned earlier, these datums are not applicable in the higher latitude locations. Hence, the close agreement of this biostratigraphic event with the strontium data further supports the use of the alternative marker species Reticulofenestra oamaruensis to approximate the highlatitude Eocene/Oligocene boundary.

\section{Site 757}

The strontium data for Site 757 are listed in Table 5 and shown in Figure 9. The ${ }^{87} \mathrm{Sr} /{ }^{86} \mathrm{Sr}$ values uniformly increase with decreasing depth in the section (Fig. 9B). The uppermost sample (121$757 \mathrm{~B}-12 \mathrm{H}-1,45-46 \mathrm{~cm}, 101.25 \mathrm{mbsf}$ ) is assigned an age of 27.48 $\mathrm{Ma}$ and the lowermost (Sample 121-757B-14H-6, 45-46 cm, $128.05 \mathrm{mbsf}$ ), an age of $38.49 \mathrm{Ma}$ (Fig. 9A). Within our sample resolution, no apparent hiatuses can be detected by strontium analysis in this section, although it is more condensed than those discussed earlier. However, the preliminary nannofossil stratigraphy would indicate that middle Oligocene Zones CP17-CP18 are missing in this section (P. Resiwati, pers. comm.). As shown in Figure 10 , the nannofossil and strontium ages are systematically offset by no more than $2.5 \mathrm{Ma}$ with the strontium values indicating slightly older dates. Because of this offset, it appears from this site that strontium ages for the lower and uppermost Oligocene are less consistent with the biostratigraphically determined ages at these low latitudes $\left(30^{\circ}-35^{\circ} \mathrm{S}\right)$ than in the higher latitude sections.

\section{ACKNOWLEDGMENTS}

This study was supported by Leg 119-121 USSAC funds to W.W., S.W.W., and J.J.P. We thank K. G. Miller and M. D. Feigenson of Rutgers University for supplying the Sr isotope data.

\section{REFERENCES}

Barrera, E., Barron, J., and Halliday, A., in press. Strontium isotope stratigraphy of the Oligocene-lower Miocene section at Site 744, southern Indian Ocean. In Barron, J., Larsen, B., et al., Proc. ODP, Sci. Results, 119: College Station, TX (Ocean Drilling Program).

Barron, J., Larsen, B., et al., 1989. Proc. ODP, Init. Repts., 119: College Station, TX (Ocean Drilling Program).

Berggren, W. A., Kent, D. V., Flynn, J. J., and Van Couvering, J. A., 1985. Cenozoic geochronology. Geol. Soc. Am. Bull., 96:1407-1418.

Broecker, W. S., and Peng, T. H., 1982. Tracers in the Sea: Palisades, N.Y. (Lamont-Doherty Geological Observatory).

Burke, W. H, Denison, R. E., Hetherington, E. A., Koepnick, R. B., Nelson, H. F., and Otto, J. B., 1982. Variation of seawater ${ }^{87} \mathrm{Sr} /{ }^{86} \mathrm{Sr}$ throughout Phanerozoic time. Geology, 10:516-519.

DePaolo, D. J., 1986. Detailed record of the Neogene Sr isotopic evolution of seawater form DSDP Site 590B. Geology, 14:103-106.

DePaolo, D. J., and Ingram, B. L., 1985. High-resolution stratigraphy with strontium isotopes. Science, 227:938-941.

Elderfield, H., and Gieskes, J. M., 1982. Sr isotopes in interstitial waters of marine sediments from Deep Sea Drilling Project cores. Nature, 300:493-497.

Elderfield, H., Gieskes, J. M., Baker, P. A., Oldfield, R. K., Hawkesworth, C. J., and Miller, R., $1982 .{ }^{87} \mathrm{Sr} /{ }^{86} \mathrm{Sr}$ and ${ }^{18} \mathrm{O} /{ }^{16} \mathrm{O}$ ratios, interstitial water chemistry and diagenesis in deep-sea carbonate sediments of the Ontong-Java Plateau. Geochim. Cosmochim. Acta, 46:2259-2268.

Gieskes, J. M., Elderfield, H., and Palmer, M., 1986. Strontium and its isotopic composition in interstitial waters of marine carbonate sediments. Earth Planet. Sci. Lett., 77:229-235.

Hart, S. R., and Brooks, C., 1974. Clinopyroxene-matrix partitioning of $\mathrm{K}, \mathrm{Rb}, \mathrm{Cs}$, and Ba. Geochim. Cosmochim. Acta, 38:1799-1806.

Hess, J., Stott, L. D., Bender, M. L., Kennett, J. P., and Schilling, J.-G., 1989. The Oligocene marine microfossil record: an age assessment using strontium isotopes. Paleoceanography, 4:655-679.

Miller, K. G., Feigenson, M. D., Kent, D. V., and Olsson, R. K., 1988. Upper Eocene to Oligocene isotope $\left.{ }^{87} \mathrm{Sr} /{ }^{86} \mathrm{Sr}, \delta^{18} \mathrm{O}, \delta^{13} \mathrm{C}\right)$ standard section, Deep Sea Drilling Project Site 522. Paleoceanography, $3: 223-233$.

Miller, K. G., Feigenson, M. D., and Wright, J. D., 1991. Miocene isotope reference section, Deep Sea Drilling Project Site 608: An evaluation 
of isotope and biostratigraphic resolution. Paleoceanography, 6:3352.

Peirce, J. W., 1978. The northward motion of India since the Late Cretaceous. Geophys. J. R. Astron. Soc., 52:277-312.

Royer, J.-Y., and Sandwell, D. T., 1989. Evolution of the eastern Indian Ocean since the late Cretaceous: constraints from GEOSAT altimetry. J. Geophys. Res., 94:13755-13782.

Schlich, R., Wise, S. W., Jr., et al., 1989. Proc. ODP, Init Repts., 120: College Station, TX (Ocean Drilling Program).
Wei, W., Villa, G., and Wise, S. W., Jr., in press. Paleoceanographic implications of Eocene-Oligocene calcareous nannofossils from ODP Sites 711 and 748 in the Indian Ocean. In Schlich, R., Wise, S. W., Jr., et al., Proc. ODP, Sci. Results, 120: College Station, TX (Ocean Drilling Program)

Date of initial receipt: 19 November 1990

Date of acceptance: 6 December 1990

Ms 121B-182 


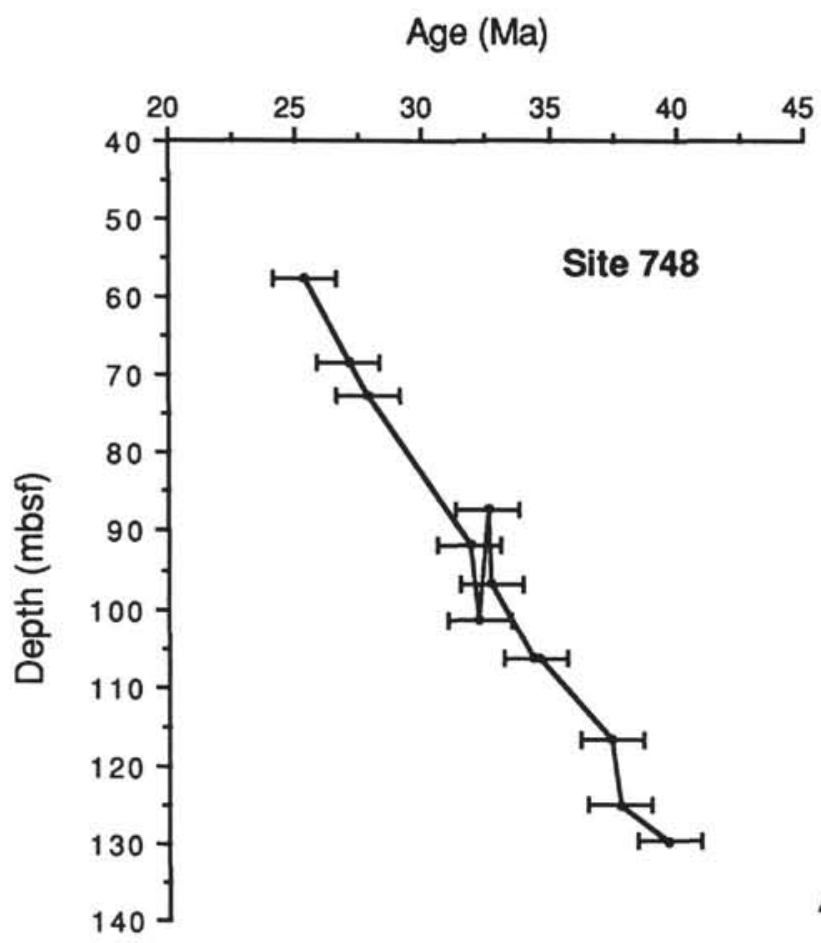

A

\section{7-Sr/86-Sr}

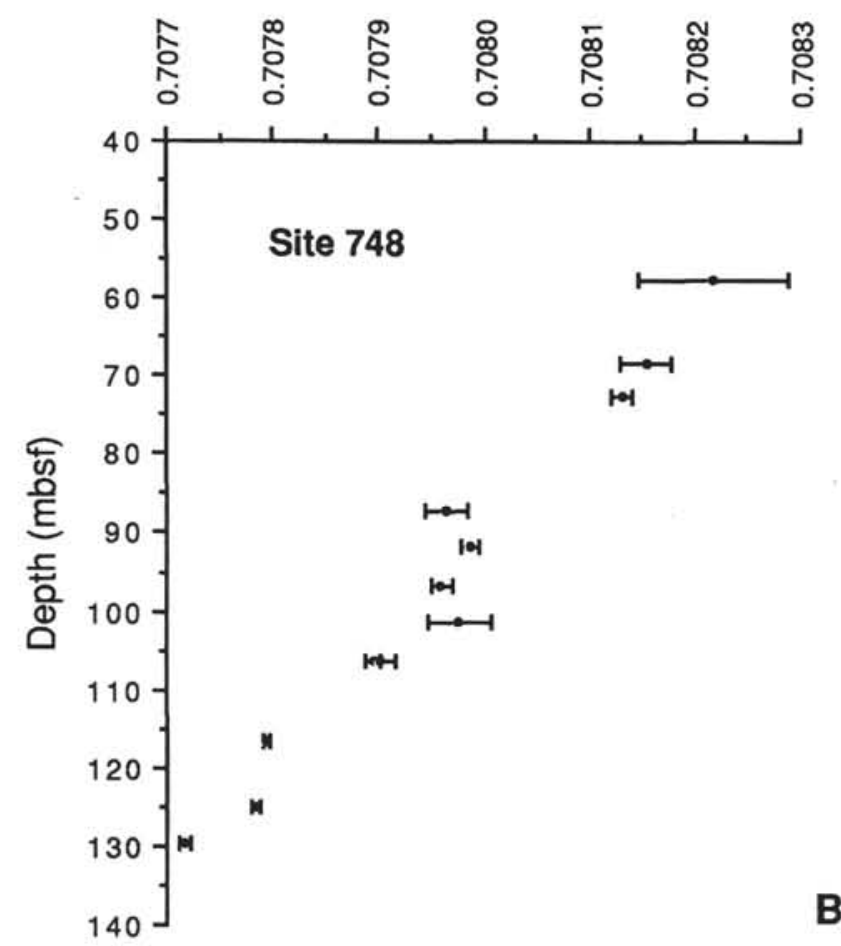

Figure 5. A. Strontium isotope age/depth plot for Kerguelen Plateau Site 748 Oligocene samples. B. Site $748{ }^{87} \mathrm{Sr} /{ }^{86} \mathrm{Sr}$ values vs. depth. (Data listed in Table 3.)

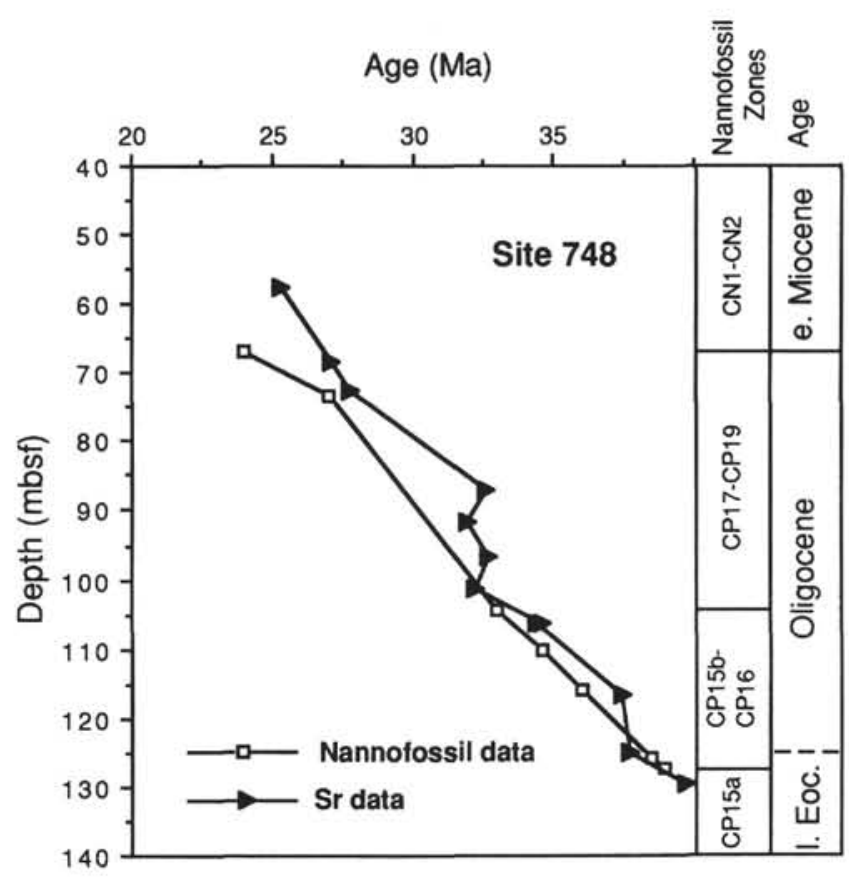

Figure 6. Age/depth plot constructed from strontium isotope values compared with calcareous nannofossil biostratigraphy for the Oligocene of Kerguelen Plateau Site 748. (Data listed in Table 3.) 
Table 4. Age and depths of ${ }^{87} \mathrm{Sr} /{ }^{86} \mathrm{Sr}$ ratios and calcareous nannofossil biostratigraphic events of samples from Ninetyeast Ridge Site 756. Sample designations B and C refer to Holes 756B and 756C, respectively.

\begin{tabular}{rcccccc}
\hline $\begin{array}{l}\text { Depth } \\
\text { (mbsf) }\end{array}$ & $\begin{array}{c}\text { Strontium } \\
\text { age (Ma) }\end{array}$ & Sample & Strontium & Error & $\begin{array}{c}\text { Depth } \\
\text { (mbsf) }\end{array}$ & $\begin{array}{c}\text { Biostratigraphic } \\
\text { age (Ma) }\end{array}$ \\
\hline 67.55 & 24.60 & B $8-2,45-46 \mathrm{~cm}$ & 0.708241 & 0.000008 & 72.07 & 25.2 \\
72.05 & 25.64 & B $8-5,45-46 \mathrm{~cm}$ & 0.708205 & 0.000006 & 79.67 & 28.2 \\
77.15 & 28.40 & B $9-2,45-46 \mathrm{~cm}$ & 0.708109 & 0.000006 & 115.47 & 34.2 \\
81.65 & 29.26 & B $9-5,45-46 \mathrm{~cm}$ & 0.708079 & 0.000007 & 121.47 & 34.6 \\
91.35 & 32.94 & B $10-5,45-46 \mathrm{~cm}$ & 0.707951 & 0.000000 & 131.77 & 36.7 \\
96.55 & 35.27 & B $11-2,45-46 \mathrm{~cm}$ & 0.707870 & 0.000006 & & \\
101.05 & 35.27 & B $11-5,45-46 \mathrm{~cm}$ & 0.707870 & 0.000001 & & \\
102.85 & 29.57 & C $4-2,45-46 \mathrm{~cm}$ & 0.708068 & 0.000007 & & \\
102.85 & 30.81 & C $4-2,45-46 \mathrm{~cm}$ & 0.708025 & 0.000012 & & \\
107.35 & 31.79 & C $4-5,45-46 \mathrm{~cm}$ & 0.707991 & 0.000007 & & \\
111.27 & 31.07 & C $5-2,45-46 \mathrm{~cm}$ & 0.708016 & 0.000015 & & \\
111.97 & 32.48 & C 5-3, 45-46 cm & 0.707967 & 0.000006 & & \\
113.91 & 33.40 & C $5-5,45-46 \mathrm{~cm}$ & 0.707935 & 0.000006 & & \\
114.73 & 33.00 & C 5-6, $45-46 \mathrm{~cm}$ & 0.707949 & 0.000008 & & \\
122.15 & 36.51 & C $6-2,45-46 \mathrm{~cm}$ & 0.707827 & 0.000006 & & \\
126.65 & 36.36 & C $6-5,45-46 \mathrm{~cm}$ & 0.707832 & 0.000005 & & \\
131.75 & 37.25 & C $7-2,45-46 \mathrm{~cm}$ & 0.707801 & 0.000005 & & \\
136.25 & 37.54 & C $7-5,45-46 \mathrm{~cm}$ & 0.707791 & 0.000010 & & \\
\hline
\end{tabular}

Table 5. Age and depths of ${ }^{87} \mathrm{Sr} /{ }^{86} \mathrm{Sr}$ ratios and calcareous nannofossil biostratigraphic events of samples from Ninetyeast Ridge Site 757.

\begin{tabular}{ccccccc}
\hline $\begin{array}{c}\text { Depth } \\
\text { (mbsf) }\end{array}$ & $\begin{array}{c}\text { Strontium } \\
\text { age (Ma) }\end{array}$ & Sample & Strontium & Error & $\begin{array}{c}\text { Depth } \\
\text { (mbsf) }\end{array}$ & $\begin{array}{c}\text { Biostratigraphic } \\
\text { age (Ma) }\end{array}$ \\
\hline 101.25 & 27.477 & $12-1,45-46 \mathrm{~cm}$ & 0.708141 & 0.000005 & 101.27 & 25.2 \\
104.25 & 29.316 & $12-3,45-46 \mathrm{~cm}$ & 0.708077 & 0.000006 & 107.27 & 28.2 \\
110.95 & 33.113 & $13-1,45-46 \mathrm{~cm}$ & 0.707945 & 0.000012 & 110.97 & 30.2 \\
116.95 & 35.125 & $13-5,45-46 \mathrm{~cm}$ & 0.707875 & 0.000005 & 118.47 & 35.1 \\
120.55 & 36.133 & $14-1,45-46 \mathrm{~cm}$ & 0.707840 & 0.000020 & 125.07 & 36.7 \\
128.05 & 38.490 & $14-6,45-46 \mathrm{~cm}$ & 0.707758 & 0.000008 & & \\
\hline
\end{tabular}



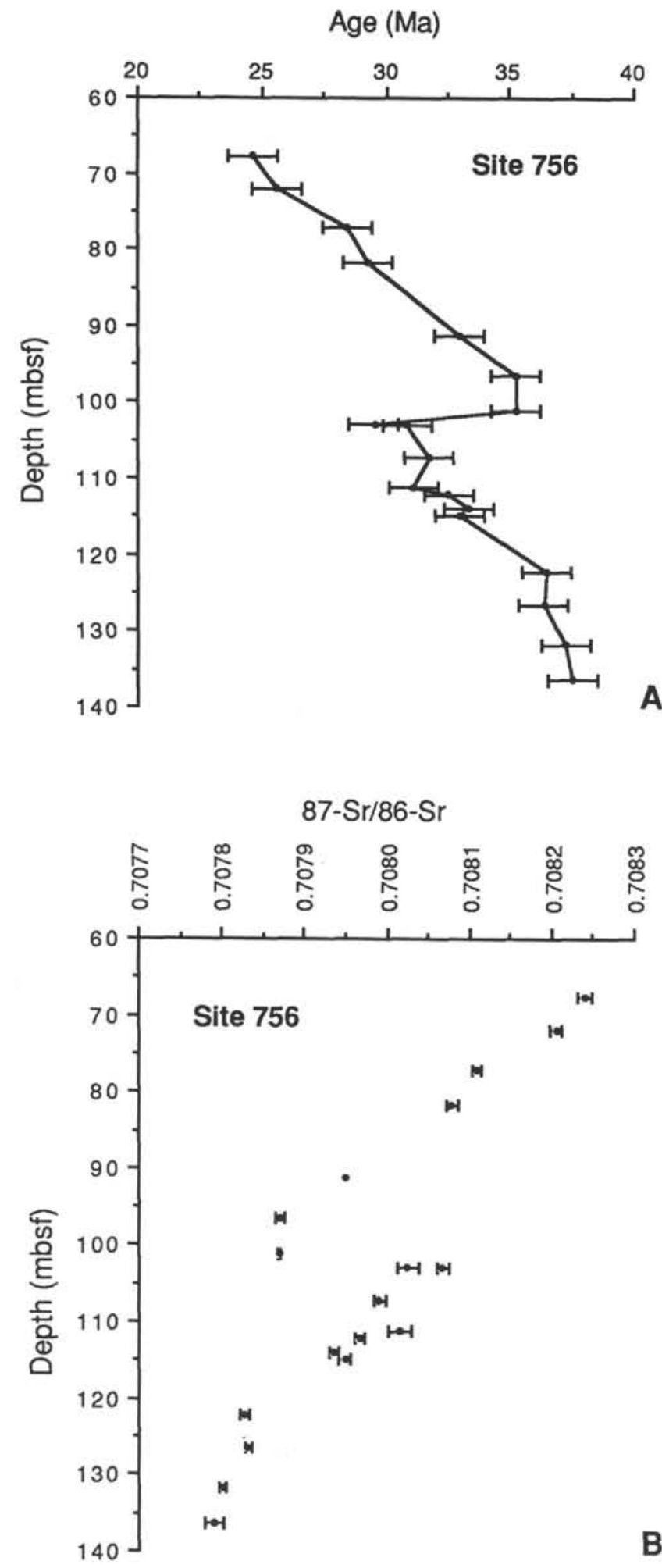

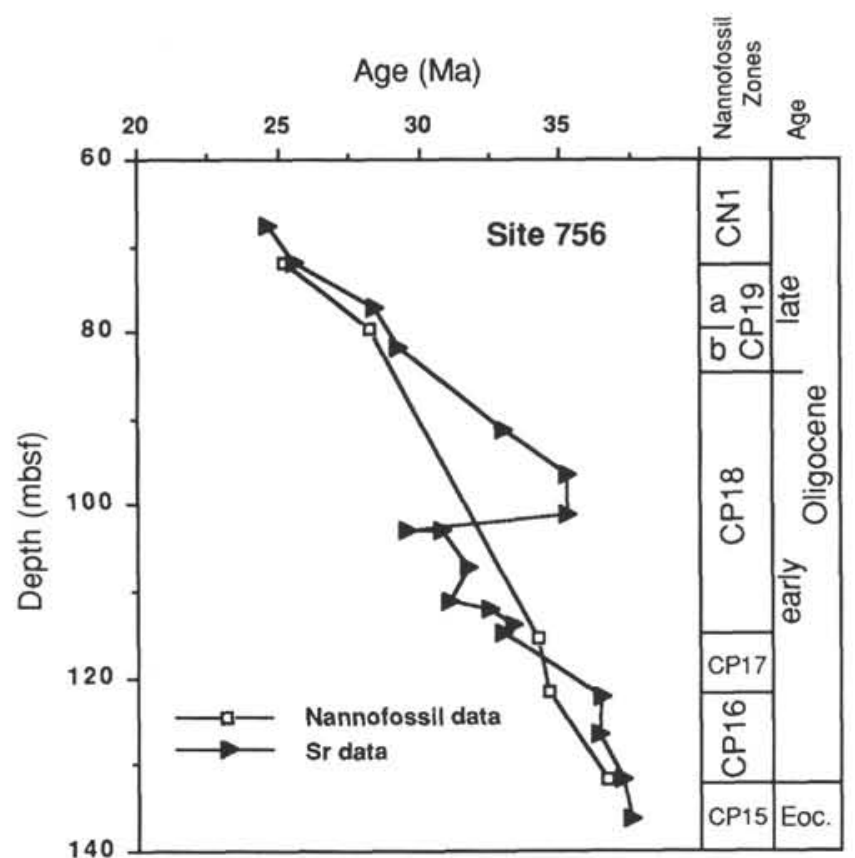

Figure 8. Age/depth plot constructed from strontium isotope values compared with calcareous nannofossil biostratigraphy for the Oligocene of Ninetyeast Ridge Site 756. (Data listed in Table 4.)

Figure 7. A. Strontium isotope age/depth plot for Ninetyeast Ridge Site 756 Oligocene samples. B. Site $756^{87} \mathrm{Sr} / 86 \mathrm{Sr}$ values vs, depth. (Data listed in Table 4.) 

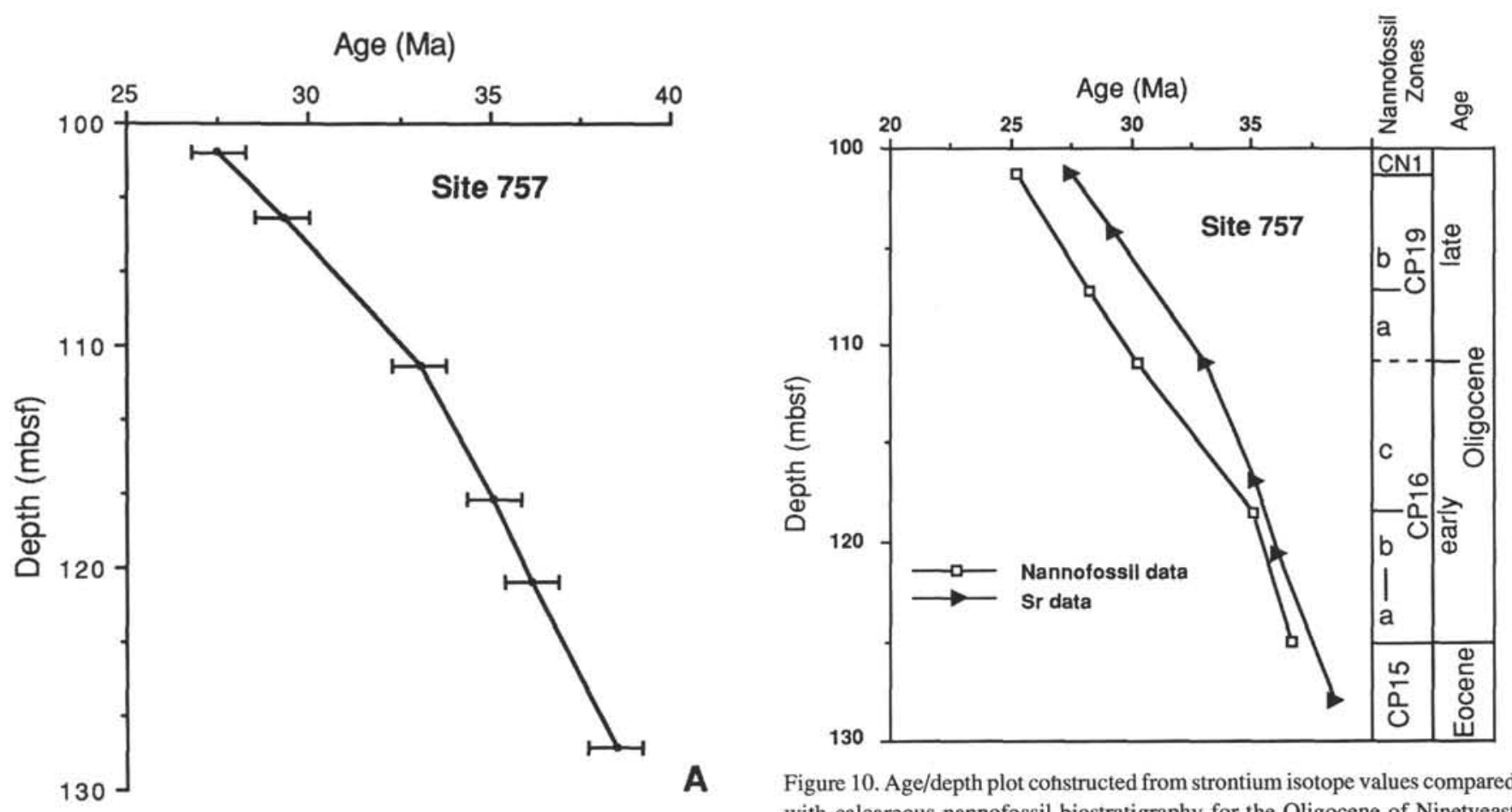

A Figure 10. Age/depth plot constructed from strontium isotope values compared with calcareous nannofossil biostratigraphy for the Oligocene of Ninetyeast Ridge Site 757. (Data listed in Table 5.)

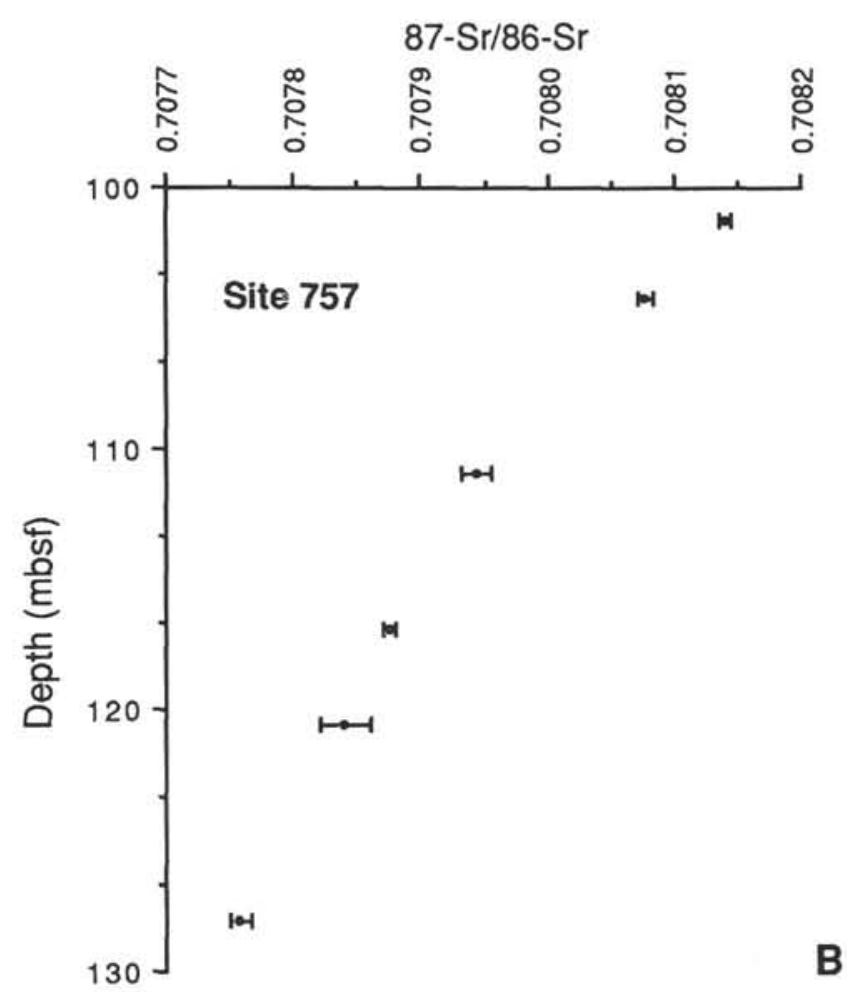

APPENDIX

Preliminary Strontium Data from Sites 329, 513, 689, and 690

\begin{tabular}{lcclll}
\hline & $\begin{array}{c}\text { Depth } \\
\text { (mbsf) }\end{array}$ & $\begin{array}{c}\text { Strontium } \\
\text { age (Ma) }\end{array}$ & Sample & Strontium & Error \\
\hline Site 329 & 361.07 & 30.008 & $329-27$ & 0.708053 & 0.000018 \\
& 388.93 & 18.992 & $329-28$ & 0.708436 & 0.000071 \\
& 411.80 & 32.537 & $329-30$ & 0.707965 & 0.000004 \\
Site 513 & 328.30 & 32.307 & $513 \mathrm{~A}-28$ & 0.707973 & 0.000011 \\
& 351.98 & 34.348 & $513 \mathrm{~A}-31$ & 0.707902 & 0.000028 \\
Site 689 & 107.29 & 31.271 & $689 \mathrm{~B}-12 \mathrm{H}$ & 0.708009 & 0.000014 \\
& 113.40 & 31.703 & $689 \mathrm{~B}-13 \mathrm{H}$ & 0.707994 & 0.000028 \\
Site 690 & 88.66 & 28.914 & $690 \mathrm{~B}-10 \mathrm{H}$ & 0.708091 & 0.000042 \\
& 90.40 & - & $690 \mathrm{~B}-11 \mathrm{H}$ & 0.708053 & 0.000071 \\
\hline
\end{tabular}

Figure 9. A. Strontium isotope age/depth plot for Ninetyeast Ridge Site 757 Oligocene samples. B. Site $757^{87} \mathrm{Sr} /{ }^{86} \mathrm{Sr}$ values vs. depth. (Data listed in Table 5.) 